Sains Malaysiana 50(12)(2021): 3557-3567

http://doi.org/10.17576/jsm-2021-5012-08

\title{
Pengenalpastian Bakteria Tanah yang Mempunyai Aktiviti Antikulat terhadap Patogen Kelapa Sawit, Ganoderma boninense
}

(Identification of Soil Bacteria with Antifungus Activity towards Palm Oil Pathogen, Ganoderma boninense)

\author{
Aqilah Yusoff, Fatin Humairah M. AshaAri, Muhammad Asyraff AbD Samad, \\ ANIS FARHAN FATIMI AB WAHAB \& IZWAN BHARUDIN*
}

\begin{abstract}
ABSTRAK
Penyakit reput pangkal batang (BSR) yang berpunca daripada kulat fitopatogen Ganoderma boninense merupakan ancaman terbesar kepada tanaman kelapa sawit di Malaysia. BSR menyebabkan pengurangan hasil tandan sawit dan kematian terhadap pokok kelapa sawit terjangkit, seterusnya menyebabkan kerugian yang besar kepada ekonomi negara pengeluar. Penggunaan racun kimia juga telah diaplikasikan bagi menangani BSR, namun begitu, kaedah ini tidak mampu mengatasi serangan kulat ini. Beberapa kajian telah dilakukan untuk mengenal pasti potensi penggunaan agen kawalan biologi seperti mikroorganisma antagonis dalam mengawal penyakit BSR. Kajian ini bertujuan untuk mengenal pasti mikroorganisma pencilan tempatan yang mempunyai kesan antagonistik terhadap G. boninense. Sebanyak 49 kultur bakteria tulen telah dipencilkan dari kawasan sekitar Bangi, Selangor, Malaysia. Tiga pencilan iaitu masing-masing dua strain daripada genus Burkholderia dan satu daripada Streptomyces menunjukkan aktiviti antagonistik yang kuat terhadap miselia dwikarion G. boninense strain PER71 dengan nilai Peratusan Perencatan Pertumbuhan Radius (PIRG) melebihi 70\% dalam dua asai antikulat yang berbeza. Analisis jujukan DNA bagi semua pencilan telah menunjukkan spesies bakteria tersebut mempunyai kesamaan yang tinggi dengan jujukan nukleotida 16S rRNA daripada Burkholderia stagnalis, B. cepacia dan Streptomyces gelaticus. Bakteria yang digunakan di dalam kajian ini mempunyai potensi yang tinggi untuk digunakan sebagai agen kawalan biologi dalam menghalang penyebaran $\mathrm{G}$. boninense terutamanya di dalam ladang kelapa sawit di Malaysia.
\end{abstract}

Kata kunci: Antagonis; BSR; Burkholderia; kawalan biologi; kulat patogen; Streptomyces

\section{ABSTRACT}

Basal Stem Rot disease (BSR) caused by the phytopathogenic fungus Ganoderma boninense is a huge threat to the oil palm plantations in Malaysia. BSR can reduce the yield of oil palm fruit bunch and cause fatality on infected oil palm trees thus creating huge economic losses to the producing country. The use of chemical fungicides has been applied in addressing BSR, however these methods were unable to overcome the fungal attack. A few studies have been carried out to identify the potential of biological control agents such as antagonistic microorganisms in controlling BSR disease. This study aimed to identify locally isolated microorganisms having antagonistic effects against $\mathrm{G}$. boninense. A total of 49 pure bacterial cultures were isolated from Bangi, Selangor, Malaysia. Three isolates namely two from genus Burkholderia and one from Streptomyces showed strong antagonistic activity against G. boninense dikaryotic micellia with more than $70 \%$ of Percentage Inhibition of Radial Growth (PIRG) in two different antifungal assays. DNA sequence analysis of all isolates showed that the bacteria species shared high similarities in their 16S rRNA sequences with Burkholderia stagnalis, B. cepacia and Streptomyces gelaticus. The bacteria found in this study have high potentials to be used as biological control agents in preventing the spread of $\mathrm{G}$. boninense, particularly in the oil palm plantations in Malaysia.

Keywords: Antagonist; biological control; BSR; Burkholderia; fungal pathogen; Streptomyces

\section{PENGENALAN}

Kelapa sawit (Elaeis guineensis) merupakan tanaman komoditi yang terpenting di Malaysia. Kelapa sawit telah menyumbangkan pendapatan yang tinggi kepada negara serta membantu merendahkan kadar kemiskinan di Malaysia (Lim et al. 2018a). Pada tahun 2019, hasil eksport daripada tanaman dan produk kelapa sawit telah menyumbangkan pendapatan sebanyak RM 64.84 bilion yang merangkumi keluasan tanaman sebanyak 5.9 juta hektar (Kushairi et al. 2019). Oleh itu, tahap kesihatan 
pokok kelapa sawit merupakan salah satu faktor penting bagi mendapatkan hasil yang maksimum.

Namun begitu, tanaman kelapa sawit di Asia Tenggara telah diancam oleh pelbagai jenis perosak seperti ulat bungkus dan kumbang (Halim et al. 2017; Luqman et al. 2018) dan penyakit seperti reput pangkal batang (BSR) yang disebabkan oleh kulat fitopatogen, Ganoderma boninense (Lim et al. 2018a; Madihah et al. 2018). Penyakit BSR menyebabkan kerugian besar kepada negara pengeluar kelapa sawit seperti Malaysia dan Indonesia dengan anggaran kerugian sehingga RM1.5 bilion setahun (Arif et al. 2011; Isaac et al. 2018). Kirakira 3450.7 hektar kawasan ladang yang diusahakan oleh pengusaha kecil di seluruh Malaysia mengalami masalah BSR (Ibrahim et al. 2020).

Sehingga kini, tiada kaedah berkesan yang dapat mencegah serangan kulat $G$. boninense pada pokok kelapa sawit. Kaedah tradisi seperti penggalian parit, penutupan tanah dan sanitasi tidak dapat menghapuskan serangan kulat fitopatogen ini (Hushiarian et al. 2013). Penggunaan bahan kimia seperti fungisida juga telah digunakan (Maznah et al. 2015), namun begitu, ujian lapangan fungisida adalah kurang berkesan di samping merosakkan ekosistem persekitaran (Priwiratama \& Susanto 2014). Selain itu, kaedah ini juga memberikan impak negatif kepada persekitaran seperti pengurangan populasi mikrob yang berguna dan pengumpulan bahan kimia-fungisid di dalam tisu akar pokok (Chong et al. 2017). Tambahan pula, penggunaan fungisid secara berulang-ulang juga boleh menyebabkan masalah kesihatan dan persekitaran serta meningkatkan kerintangan kulat patogen terhadap bahan kimia khusus (Maznah et al. 2015).

Kini, ramai penyelidik bertukar kepada penggunaan agen kawalan biologi dalam menangani masalah penyakit disebabkan oleh fitopatogen (Nusaibah et al. 2017). Mikroorganisma seperti bakteria (Bacillus amyloliquefaciens, B. subtilis dan Pseudomonas putida) dan kulat (Trichoderma harzianum, Verticillium lecanii dan Beauveria bassiana) menjadi pilihan agen kawalan biologi terhadap penyakit tumbuhan kerana mikroorganisma tersebut tidak menghasilkan bahan toksik dan selamat terhadap manusia dan persekitaran (Hong \& Park 2016; Singh et al. 2018). Tanah merupakan sumber terbaik untuk pemencilan calon yang berpotensi sebagai agen kawalan biologi kerana ia mengandungi kepelbagaian komuniti mikrob yang berkebolehan untuk menghasilkan pelbagai metabolit bioaktif yang berguna (Nadarajah 2016) seperti metabolit yang berpotensi untuk merencat pertumbuhan patogen tumbuhan dan juga yang berpotensi untuk menggalakkan pertumbuhan akar bagi membantu kesuburan tumbuhan. Oleh itu, kajian ini dilakukan untuk mengenal pasti mikroorganisma yang berpotensi bertindak sebagai agen biokawalan kepada kulat fitopatogen, $G$. boninense yang seterusnya diharapkan dapat membantu dalam pembangunan biofungisid berasaskan mikrob yang lebih selamat dan mampan berbanding fungisida berasaskan bahan kimia untuk kelestarian industri kelapa sawit di Malaysia.

\section{BAHAN DAN KAEDAH}

\section{PEMENCILAN MIKROB}

Sampel tanah diperoleh daripada ladang kelapa sawit berhampiran Desa Vista (2॰50'22.8”N 10144'23.2”E) dan Hutan Simpan Bangi (2॰55'09.8’N 10146’02.1'E), Selangor, Malaysia. Sampel tanah tersebut diletakkan di dalam beg yang steril dan dipindahkan ke dalam makmal dalam tempoh 24 jam untuk pemencilan mikrob. Sebanyak $1 \mathrm{~g}$ sampel tanah dilarutkan dengan $9 \mathrm{~mL}$ air suling yang steril dan dilakukan pencairan bersiri sehingga $10^{-5}$. Sebanyak $0.1 \mathrm{~mL}$ sampel daripada setiap pencairan bersiri dikulturkan di atas piring agar nutrien (Difco, USA) dan dieramkan pada suhu $28^{\circ} \mathrm{C}$ selama 24 hingga 72 jam. Semua koloni tunggal yang mempunyai ciri saiz, warna dan morfologi berbeza dipindahkan ke dalam piring agar baru untuk analisis seterusnya.

\section{PEMILIHAN KULTUR TULEN BAKTERIA YANG MEMPUNYAI AKTIVITI ANTIKULAT}

Semua kultur tulen yang dipencilkan diuji tahap perencatannya (antagonistik) terhadap kulat $G$. boninense melalui kaedah asai pemiringan dwikultur dengan sedikit modifikasi (El Khoury et al. 2018; Ramli et al. 2016). Plak miselia dwikarion $G$. boninense ( 8 $\mathrm{mm}$ ) diinokulasikan pada bahagian tengah piring agar kentang dekstrosa (PDA) (Merck, Jerman). Kemudian, setiap kultur tulen bakteria yang telah dipencilkan diinokulasikan secara selari kira-kira $20 \mathrm{~mm}$ daripada plak miselia G. boninense. Piring-piring tersebut dieram pada suhu $28{ }^{\circ} \mathrm{C}$ dan dicerap selepas hari ke tujuh. Kekuatan tahap perencatan setiap kultur tulen bakteria terhadap $G$. boninense dalam kajian ini dikira berdasarkan formula Percentage Inhibition of Radial Growth (PIRG) (ShariffahMuzaimah et al. 2015) (Rajah 1).

\section{ASAI AKTIVITI ANTIKULAT}

Dua kaedah asai berbeza dilakukan terhadap kulat $G$. boninense PER71 (Idris Abu Seman, Malaysian Palm Oil Board; komunikasi peribadi). Asai pertama melibatkan G. boninense dikultur 2 hari lebih awal sebelum kultur tulen bakteria diinokulasikan ke dalam agar media yang 


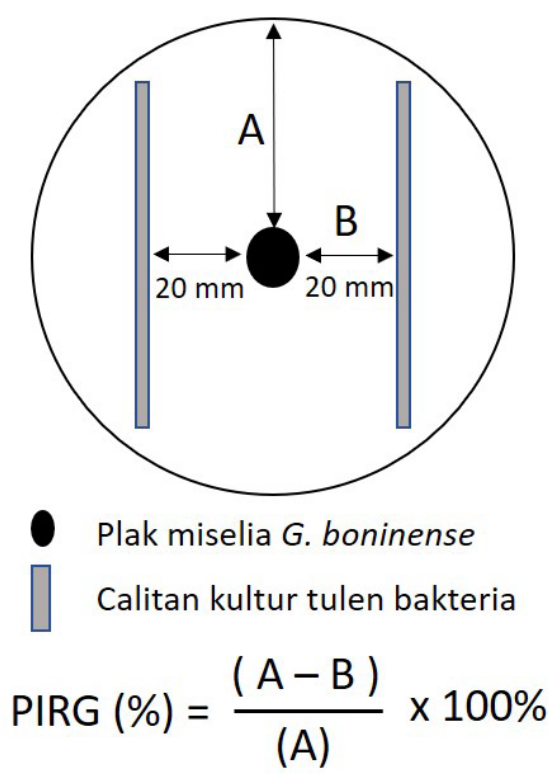

RAJAH 1. Pengiraan nilai PIRG yang digunakan dalam kajian ini

sama (Lim et al. 2018b) manakala asai kedua pula, kultur tulen bakteria diinokulasikan 5 hari lebih awal sebelum G. boninense diinokulasikan di dalam agar media yang sama (Shariffah-Muzaimah et al. 2015). Semua piring asai dieram pada suhu $28^{\circ} \mathrm{C}$ dan dicerap selepas 7 hari (dalam tiga replikasi). Pembentukan zon perencatan antara kultur tulen bakteria dan kulat $G$. boninense dibandingkan dengan piring kawalan $(G$. boninense sahaja) untuk penentuan nilai PIRG (Muniroh et al. 2019; Ramli et al. 2016; Shariffah-Muzaimah et al. 2015). Kultur tulen yang mempunyai nilai PIRG melebihi $70 \%$ dipilih untuk analisis penentuan spesies bakteria melalui kaedah penjujukan DNA.

PENJUJUKAN DNA

Pengekstrakan DNA genom dari kultur tulen bakteria terpilih (nilai PIRG $>70 \%$ ) dilakukan menggunakan penimbal ekstraksi setil-trimetil-ammonium bromida (CTAB) (100 mM Tris-HCl pH 8.4, 1.4 M NaCl, 25 mM EDTA, 2\% CTAB) diikuti dengan pemisahan klorofom. Tindak balas berantai polimerase (PCR) dilakukan menggunakan $0.125 \mu \mathrm{L}$ OneTaq ${ }^{\circledR}$ DNA Polymerase (kepekatan akhir 0.75 unit) (NEB, USA), $5 \mu \mathrm{L}$ larutan penimbal OneTaq $5 \mathrm{X}, 0.5 \mu \mathrm{L}$ dNTPs $(10 \mathrm{mM}), 2 \mu \mathrm{L}$ templat DNA (50 ng), $0.5 \mu \mathrm{L}$ pencetus kehadapan $(10 \mu \mathrm{M}) ; 27 \mathrm{~F}$ (5'-AGAGTTTGATCCTGGCTCAG-3') dan $0.5 \mu \mathrm{L}$ pencetus kehadapan $(10 \mu \mathrm{M}) ; 1492 \mathrm{R}$ (5'-GGTTACCTTGTTACGACTT-3') (Heuer et al. 1997).

Amplifikasi PCR dijalankan menggunakan kitar yang terdiri daripada satu kitar penyahaslian pada suhu
$95{ }^{\circ} \mathrm{C}$ selama 3 min diikuti dengan 30 kitar ulangan kitar penyahaslian pada suhu $94{ }^{\circ} \mathrm{C}$ selama $30 \mathrm{~s}$, penyepuhan pada suhu $50{ }^{\circ} \mathrm{C}$ selama $30 \mathrm{~s}$ dan diikuti dengan pemanjangan pada suhu $68^{\circ} \mathrm{C}$ selama 1 min yang seterusnya diikuti dengan kitar pemanjangan akhir pada suhu $68^{\circ} \mathrm{C}$ selama 5 min. Produk PCR yang terhasil dicerap melalui kaedah elektroforesis gel agarosa dan ditulenkan menggunakan kit Monarch DNA Gel Extraction Kit (NEB, USA). Produk penulenan PCR tersebut dihantar ke Syarikat Apical Scientific Sdn Bhd untuk proses penjujukan.

\section{PENENTUAN SPESIES BAKTERIA ANTAGONIS}

Jujukan DNA $16 \mathrm{~S}$ rRNA bagi sampel terpilih yang diperoleh dianalisis menggunakan perisian Basic Local Alignment Search Tool (BLAST) melalui analisis BLASTN yang terdapat pada pangkalan data National Centre for Biotechnology Information (NCBI). Jujukan DNA dianggap mempunyai kesamaan signifikan dengan jujukan dalam pangkalan data jika hasil pencarian menunjukkan nilai e kurang daripada $10^{-5}$ dan peratus identiti melebihi $90 \%$. Seterusnya, penjajaran jujukan berbilang dilakukan menggunakan perisian Muscle manakala analisis filogeni bagi jujukan separa gen 16S rRNA dijalankan menggunakan algoritma Maximum Likelihood dengan nilai butstrap 1000. Semua analisis pembinaan pohon filogeni dijalankan menggunakan pakej lengkap perisian MEGA7 (Kumar et al. 2016). Nombor aksesi bagi setiap jujukan DNA $16 \mathrm{~S}$ rRNA yang digunakan di dalam pembinaan pohon filogeni disertakan dalam Jadual 1. 
JADUAL 1. Spesies bakteria berserta nombor aksesi bagi setiap jujukan DNA 16S rRNA separa yang digunakan di dalam pembinaan pohon filogeni

\begin{tabular}{lc}
\hline \multicolumn{1}{c}{ Spesies bakteria } & Nombor aksesi GenBank \\
\hline Burkholderia sp. UKM1 (B20) & MT875150 \\
Burkholderia sp. UKM2 (B24) & MT875150 \\
Burkholderia stagnalis & CP013459 \\
Burkholderia thailandensis & NR_027587 \\
Burkholderia mallei & NR_041725 \\
Burkholderia pseudomallei & LR595899 \\
Burkholderia ambifaria & KY515429 \\
Burkholderia cepacia & LC507962 \\
Streptomyces sp. UKM1 (B39) & MT249312 \\
Streptomyces coelicolor & NR_112305 \\
Streptomyces celluloflavus & MN428227 \\
Streptomyces gelaticus & MN421123 \\
Streptomyces gilvosporeus & CP020569 \\
Nocardiopsis prasina & NR_044906 \\
Nocardiopsis lucentensis & MN004812 \\
Bacillus lehensis & NR_036940 \\
Bacillus subtilis & MT372489 \\
Bacillus cereus & CP053954 \\
Bacillus gibsonii & NR_026143 \\
Micromonospora aurantiaca & NR_026279 \\
Micromonospora nigra & NR_044885 \\
Micromonospora oryzae & NR_145609 \\
Aminobacter aminovorans & NR_025301 \\
Aminobacter ciceronei & NR_041700 \\
\hline & \\
\hline
\end{tabular}

\section{ANALISIS STATISTIK}

Analisis statistik $t$-test dilakukan menggunakan perisian Minitab bagi menentukan kejituan nilai PIRG setiap kultur tulen bakteria terhadap pertumbuhan $G$. boninense in vitro.

\section{HASIL DAN PERBINCANGAN}

\section{PEMENCILAN KULTUR TULEN BAKTERIA}

Sebanyak 49 kultur tulen bakteria berjaya dipencilkan berdasarkan perbezaan morfologi. Daripada jumlah tersebut, sebanyak 13 kultur tulen (B37-B49) menunjukkan ciri-ciri aktinobakteria seperti kewujudan spora berdebu dan menghasilkan bau tanah. Seperti mana yang diketahui, ekosistem tanah didominasi oleh populasi mikrob yang berbeza termasuklah bakteria, yis dan kulat yang memainkan peranan penting dalam memastikan kitaran nutrien tanah yang berperanan dalam memastikan kesihatan dan nutrisi tumbuhan. Selain itu, kajian terdahulu mendapati bahawa populasi bakteria tanah juga dipengaruhi oleh suhu dan sumber nutrien pada tanah tersebut (Naher et al. 2019). Selain itu, bakteria tanah terutamanya aktinobakteria juga mempunyai pelbagai fungsi biologi seperti penggalak pertumbuhan pokok (Retnowati et al. 2018) dan agen kawalan biologi (Sujarit et al. 2020).

\section{PENYARINGAN KULTUR TULEN BAKTERIA YANG MEMPUNYAI KESAN ANTAGONISTIK TERHADAP G. boninense}

Tahap kekuatan kesan perencatan terhadap kulat dwikarion G. boninense secara in vitro bagi kesemua 49 kultur tulen tersebut disaring. Kulat dwikarion G. boninense digunakan kerana kulat ini hanya patogenik dalam fasa dwikarion 
dan tidak patogenik dalam fasa monokarion (Madihah et al. 2019). Pembentukan zon perencatan antara kultur tulen tersebut dengan $G$. boninense (Rajah 2) menunjukkan tiga kultur tulen bakteria yang mempunyai perencatan kuat $(++)($ PIRG $=70-100 \%)$, enam kultur tulen bakteria dengan perencatan sederhana $(+)(\mathrm{PIRG}=40-69 \%)$ dan 40 lagi tiada kesan perencatan $(-)(P I R G=0-39 \%)($ Jadual 2).
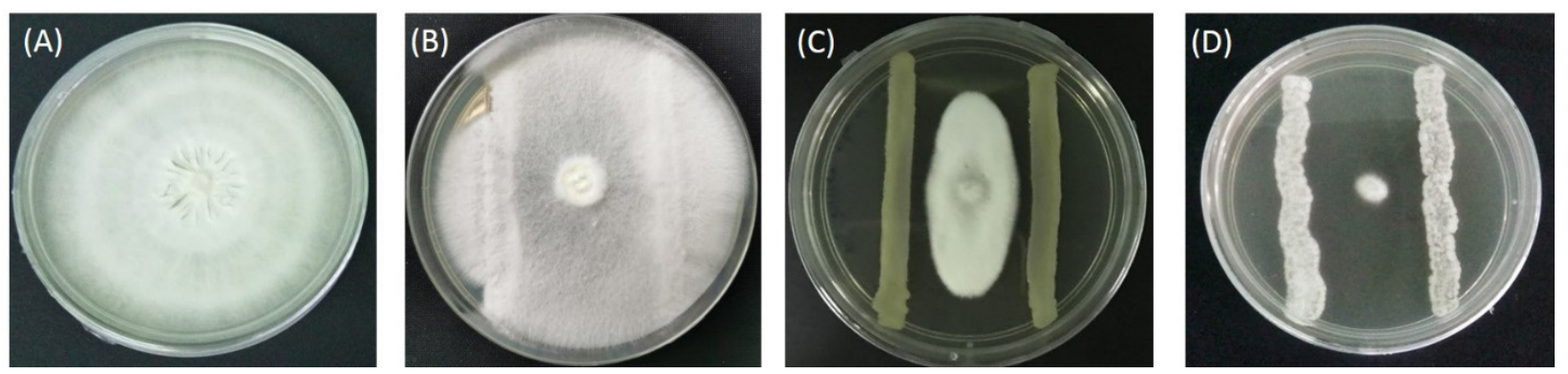

RAJAH 2. Contoh kekuatan kesan perencatan kultur tulen bakteria pencilan terhadap G. boninense selepas 7 hari pengkulturan: (A) G. boninense sahaja (kawalan), (B) tiada perencatan bakteria (pencilan B2) terhadap G. boninense (-), (C) perencatan sederhana bakteria (pencilan B11) terhadap G. boninense (+), dan (D) perencatan kuat bakteria (pencilan B39) terhadap G. boninense $(++)$

JADUAL 2. Kekuatan tahap perencatan setiap kultur tulen bakteria terhadap kulat G. boninense. Tiga kultur tulen bakteria (B20, B24 dan B39) mempunyai kesan perencatan yang kuat terhadap $G$. boninense

\begin{tabular}{|c|c|}
\hline Kultur tulen & Kekuatan perencatan \\
\hline B1 & + \\
\hline B2 & - \\
\hline B3 & + \\
\hline B4 & - \\
\hline B5 & - \\
\hline B6 & - \\
\hline B7 & - \\
\hline B8 & - \\
\hline B9 & - \\
\hline B10 & - \\
\hline B11 & + \\
\hline B12 & - \\
\hline B13 & - \\
\hline B14 & - \\
\hline B15 & - \\
\hline B16 & - \\
\hline B17 & - \\
\hline B18 & - \\
\hline B19 & + \\
\hline B20 & ++ \\
\hline B21 & - \\
\hline B22 & - \\
\hline B23 & - \\
\hline
\end{tabular}




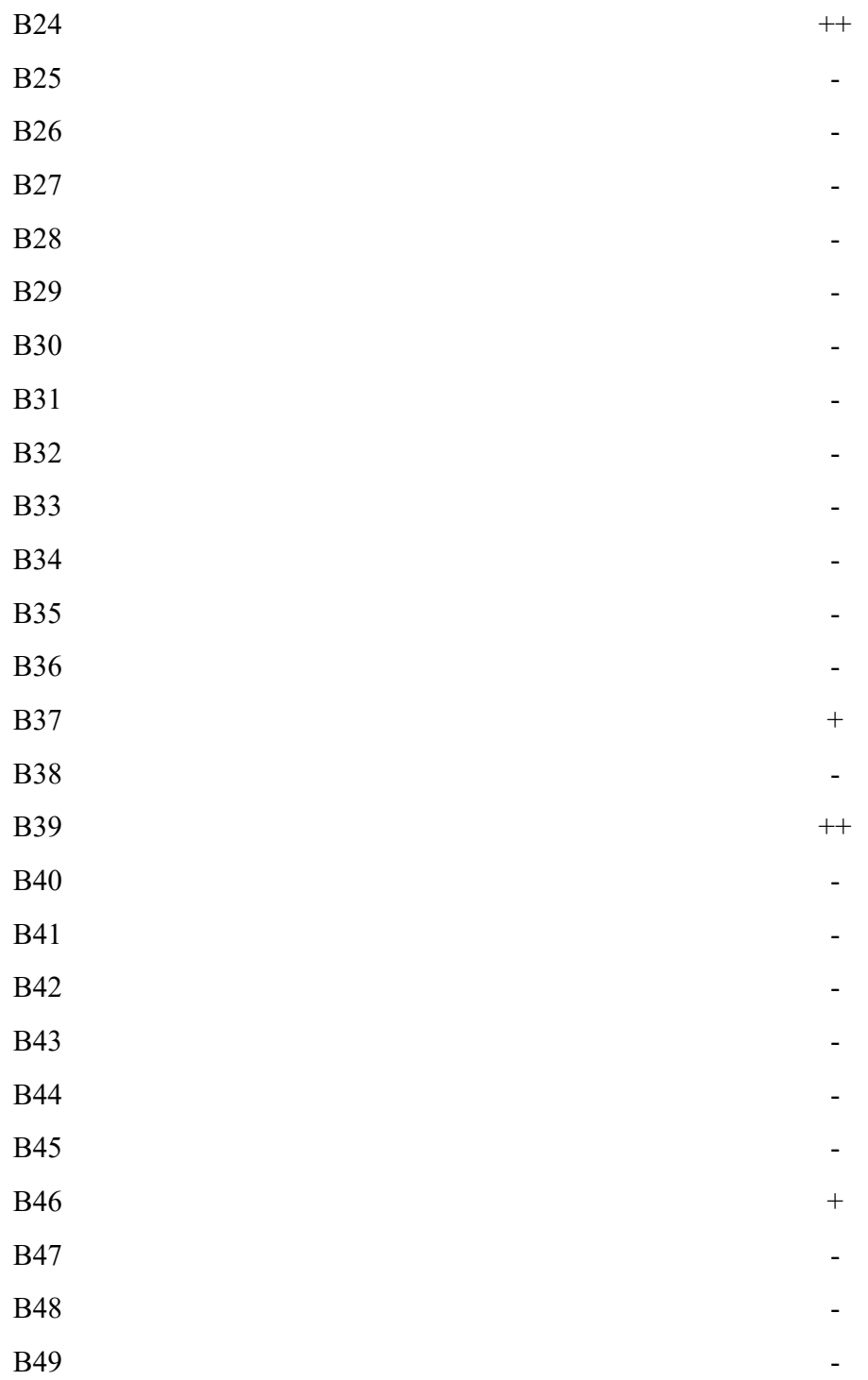

Petunjuk: (-) Tiada perencatan (PIRG = 0-39\%); (+) Perencatan sederhana (PIRG = 40-69\%); (++) Perencatan kuat $(\mathrm{PIRG}=70-100 \%)$

Tiga kultur tulen yang mempunyai kesan perencatan kuat dipilih untuk dua asai aktiviti antikulat yang berbeza. Di dalam asai antikulat pertama, ketiga-tiga kultur tulen bakteria memberikan nilai PIRG melebihi 70\% (Rajah 3). Kemudian, asai antikulat kedua (Rajah 4) dan didapati bahawa kesemua kultur tulen tersebut memberikan nilai PIRG yang lebih tinggi pada asai antikulat kedua berbanding asai antikulat pertama iaitu melebihi $90 \%$ (Jadual 3). Asai antikulat pertama dilakukan untuk menguji keupayaan kultur tulen bakteria dalam merencat pertumbuhan $G$. boninense sedia ada manakala asai antikulat kedua pula menunjukkan keberkesanan kultur tulen tersebut dalam merencat pertumbuhan $G$. boninense. Kehadiran kultur tulen tersebut pada persekitaran tanah asal berkemungkinan mempengaruhi pertumbuhan kulat $G$. boninense di dalam ladang kelapa sawit tersebut. Kajian sebelum ini menunjukkan mikroorganisma yang mempunyai nilai PIRG melebihi 80\% mempunyai potensi untuk digunakan sebagai agen kawalan biologi bagi mengatasi masalah G. boninense (Lim et al. 2018b; Ramli et al. 2016; Shariffah-Muzaimah et al. 2015). Kumpulan kultur tulen bakteria ini berkemungkinan menghasilkan metabolit sekunder yang merupakan sebatian antikulat khusus yang mampu merencat pertumbuhan $G$. boninense. 

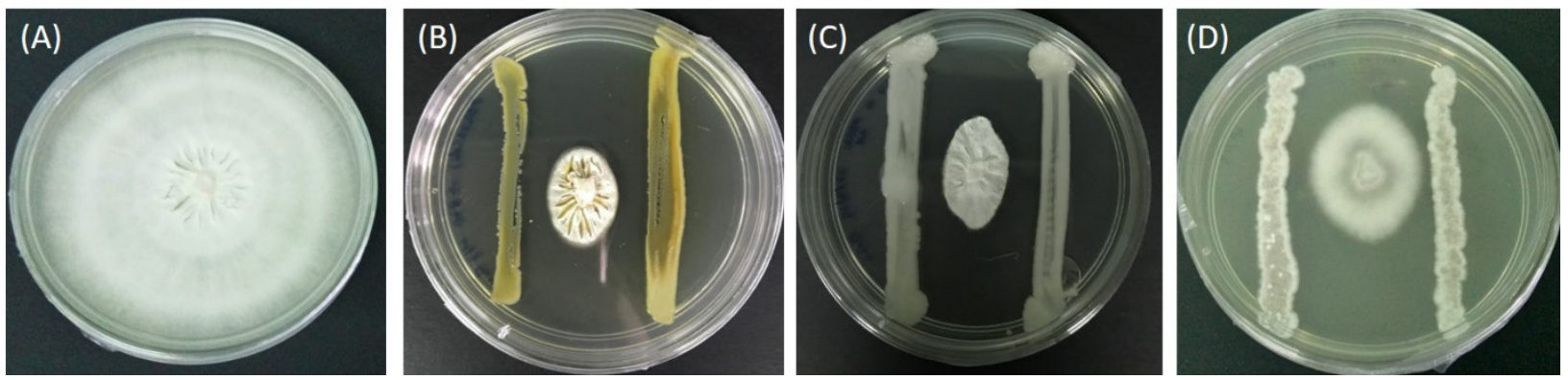

RAJAH 3. Asai kultur dwipiring G. boninense yang dihidupkan dua hari awal sebelum kultur tulen dihidupkan di atas piring media: (A) G. boninense sahaja (kawalan), (B) kultur tulen B20 (Burkholderia sp. UKM1) terhadap G. boninense, (C) kultur tulen B24 (Burkholderia sp. UKM2) terhadap G. boninense, dan (D) kultur tulen B39 (Streptomyces sp. UKM1) terhadap G. boninense
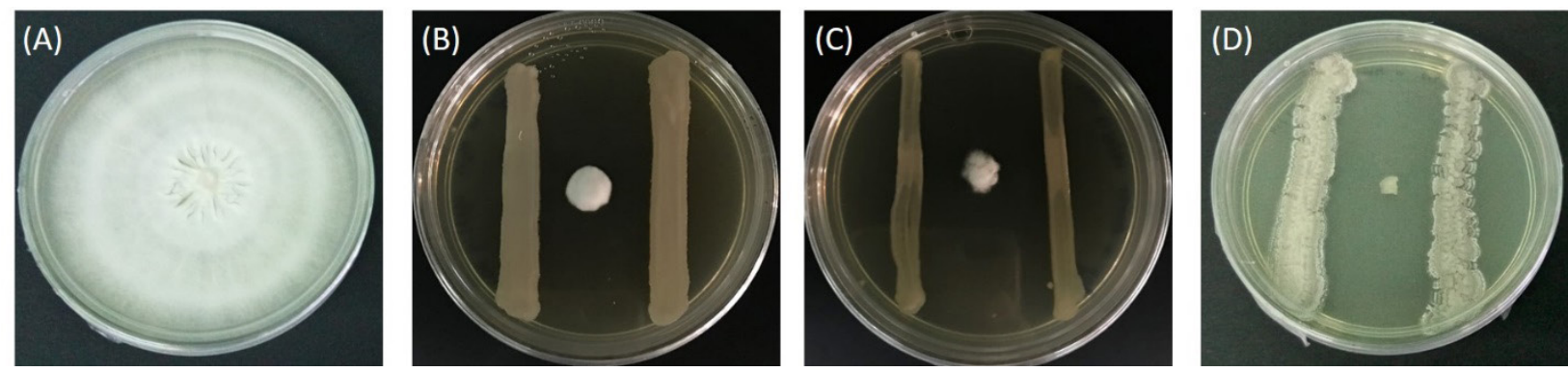

RAJAH 4. Asai kultur dwipiring kultur tulen yang dihidupkan lima hari awal sebelum G. boninense dikultur dalam piring agar yang sama: (A) G. boninense sahaja (kawalan), (B) kultur tulen B20 (Burkholderia sp. UKM1) terhadap G. boninense, (C) kultur tulen B24 (Burkholderia sp. UKM2) terhadap G. boninense, dan (D) kultur tulen B39 (Streptomyces sp. UKM1) terhadap G. boninense

JADUAL 3. Nilai PIRG tiga kultur tulen bakteria terhadap kulat fitopatogen $G$. boninense pada dua asai aktiviti antikulat yang berbeza. Semua kultur tulen mempunyai nilai PIRG melebihi $70 \%$ pada asai aktiviti antikulat pertama dan melebihi $90 \%$ pada asai aktiviti antikulat kedua. Nilai PIRG diperoleh daripada tiga replikasi biologi bagi setiap kultur tulen dan hasil analisis menunjukkan perbezaan yang signifikan terhadap pertumbuhan G. boninense in vitro melalui analisis $t$-test $(\mathrm{P}<0.05)$

\begin{tabular}{|c|c|c|c|c|}
\hline \multirow{5}{*}{ Kultur tulen } & \multicolumn{4}{|c|}{ Nilai PIRG (\%) } \\
\hline & Asai aktiviti antikulat & Nilai P & Asai aktiviti antikulat & Nilai P \\
\hline & pertama & & kedua & \\
\hline & (G. boninense - awal 2 & & (Bakteria - awal 5 hari) & \\
\hline & \multicolumn{4}{|l|}{ hari) } \\
\hline $\mathrm{B} 20$ & $72.0 \pm 2.1$ & 0.00014 & $90.1 \pm 1.3$ & 0.00004 \\
\hline B24 & $77.3 \pm 2.7$ & 0.00009 & $91.3 \pm 1.1$ & $7.49 \times 10^{-6}$ \\
\hline B39 & $71.9 \pm 1.6$ & 0.00016 & $>99.0 \pm 0.2$ & $8.52 \times 10^{-6}$ \\
\hline
\end{tabular}




\section{PENGENALPASTIAN SPESIES BAKTERIA DAN ANALISIS} FILOGENI

Pengenalpastian spesies terhadap tiga kultur tulen bakteria tersebut menunjukkan bakteria tersebut adalah daripada genus Burkholderia dan Streptomyces. Analisis jujukan DNA 16S rRNA bagi Burkholderia sp. UKM1 (kultur tulen B20) menggunakan program BLASTN menunjukkan bahawa jujukan tersebut mempunyai kesamaan yang tinggi dengan jujukan 16S rRNA daripada $B$. cepacia strain JCM 13196 dengan nilai identiti 99.29\% serta nilai $\mathrm{e}=0$, manakala jujukan DNA 16S rRNA Burkholderia sp. UKM2 (kultur tulen B24) pula menunjukkan kesamaan yang tinggi dengan jujukan $16 \mathrm{~S}$ rRNA daripada $B$. cepacia strain MSMB735WGS dengan nilai identiti $97.45 \%$ serta nilai e $=0$. Analisis jujukan DNA 16S rRNA bagi Streptomyces sp. UKM1 (kultur tulen B39) pula menunjukkan kesamaan yang tinggi dengan jujukan 16S
rRNA daripada $S$. gelaticus strain SK4-17 dengan nilai identiti $99.38 \%$ serta nilai e $=0$.

Semua jujukan rujukan DNA 16S rRNA untuk penjanaan pohon filogeni menggunakan kaedah Maximum-Likelihood diambil daripada pangkalan data NCBI daripada genus yang sama tetapi strain berlainan. Semua jujukan DNA 16S rRNA yang dipilih untuk analisis pohon filogeni mempunyai 95-99\% kesamaan dengan gen mengekod $16 \mathrm{~S}$ rRNA kultur tulen bakteria yang digunakan. Analisis pohon filogeni yang dilakukan telah membahagikan bakteria tersebut kepada dua klad (clade) iaitu kumpulan bakteria Gram-positif dan bakteria Gramnegatif (Rajah 5). Genus Bacillus dan semua kumpulan aktinobakteria seperti Streptomyces, Micromonospora dan Nocardiopsis adalah terkelompok dalam kumpulan bakteria Gram-positif. Kultur tulen Streptomyces UKM1 mempunyai kesamaan jujukan DNA paling tinggi dengan S. gelaticus (Rajah 5).

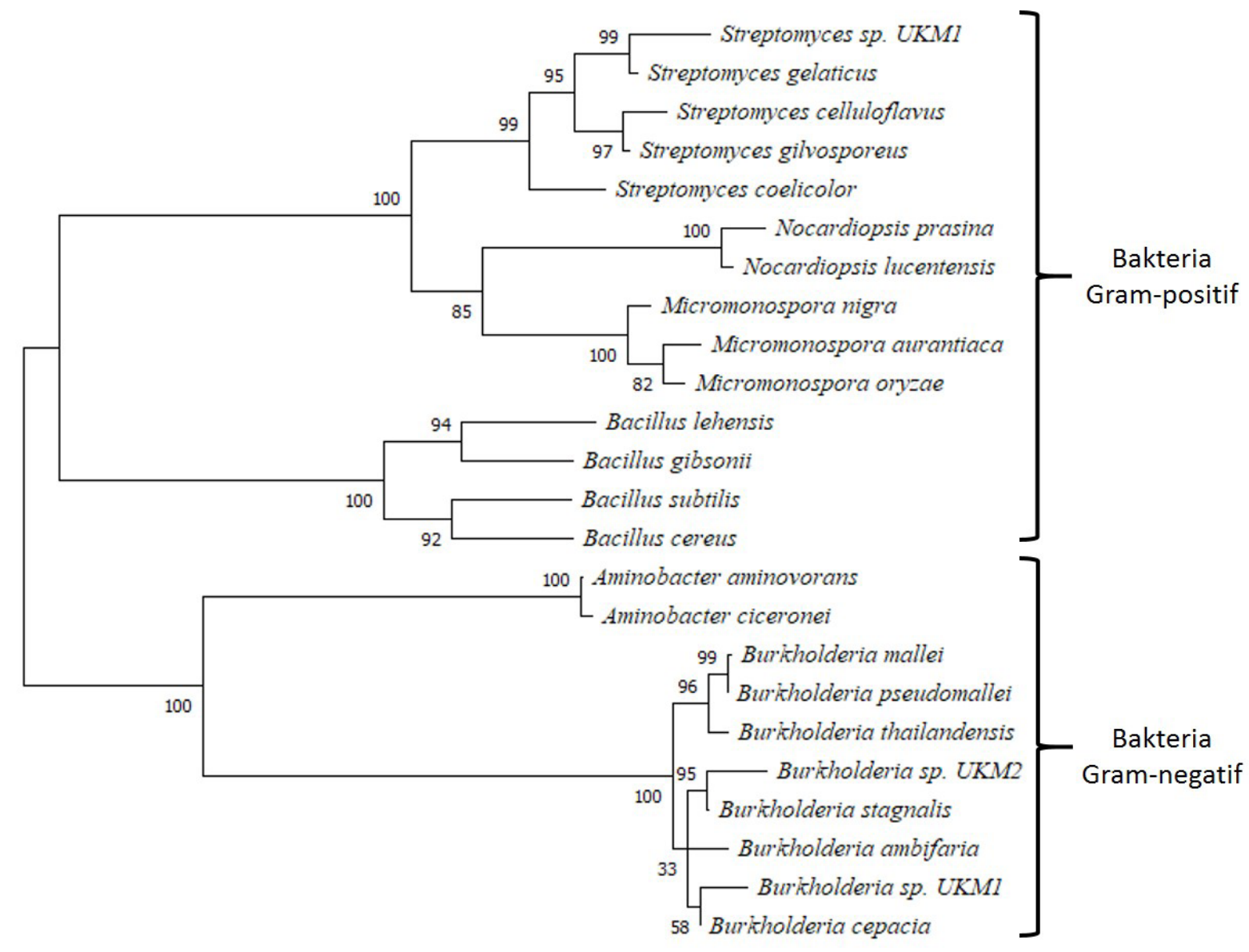

0.050

RAJAH 5. Analisis pohon filogeni terhadap semua jujukan DNA mengekod 16S rRNA kultur tulen bakteria yang diperoleh menggunakan perisian MEGA7 
Genus Streptomyces merupakan genus aktinobakteria terbesar dan dikenali sebagai mikroorganisma yang menghasilkan sebatian bioaktif yang mempunyai potensi dalam industri perubatan (Law et al. 2017). Kajian terhadap aktinobakteria pencilan tempatan, S. kebangsaanensis menunjukkan mikroorganisma tersebut menghasilkan sebatian fenazin yang mempunyai potensi sebagai antibiotik (Remali et al. 2019). Selain itu, aktinobakteria pencilan tempatan yang dikenali sebagai $S$. monashensis sp. nov. (strain MUSC $1 \mathrm{~J}^{\mathrm{T}}$ ) juga menghasilkan sebatian bioaktif yang mempunyai aktiviti antioksida dan kesan sitotoksik yang tinggi terhadap titisan sel kanser kolon HCT-116 dan SW480 (Law et al. 2019), manakala S. hygroscopicus subsp. hygroscopicus menunjukkan potensi sebagai agen kawalan biologi dalam mengawal BSR kerana berjaya mengurangkan insiden BSR pada anak pokok kelapa sawit sehingga 73.1\% (ShariffahMuzaimah et al. 2017).

Kajian lepas turut menunjukkan bahawa Streptomyces sp. juga berpotensi digunakan sebagai agen kawalan biologi bagi menangani kulat fitopatogen seperti Colletotrichum sp., penyebab utama penyakit antraknos pada cili (Shahbazi et al. 2014) dan patogen bagi penyakit karah pada padi iaitu Magnaporthe oryzae (Law et al. 2017). Namun begitu, keupayaan Streptomyces sp. untuk bertindak sebagai agen kawalan biologi mungkin dipengaruhi oleh faktor persekitaran seperti lokasi, $\mathrm{pH}$, bahan organik dan juga tahap kelembapan tanah (Law et al. 2017). Semua faktor ini menyebabkan sesetengah Streptomyces sp. yang menunjukkan potensi yang tinggi sebagai agen kawalan biologi dalam uji kaji in vitro, gagal semasa ujian lapangan (Law et al. 2017).

Satu lagi kumpulan bakteria yang menunjukkan kesan antagonis yang tinggi terhadap $G$. boninense ialah kumpulan bakteria Gram-negatif, Burkholderia sp. Analisis pohon filogeni menunjukkan kultur tulen Burkholderia UKM1 mempunyai kesamaan jujukan DNA yang tinggi dengan B. cepacia, manakala kultur tulen Burkholderia UKM2 mempunyai persamaan jujukan DNA paling tinggi dengan B. stagnalis. Kumpulan genus Burkholderia kebiasaannya terdiri daripada spesies patogen oportunis seperti B. cepacia dan B. ambifaria (Eberl \& Vandamme 2016). Walau bagaimanapun, berdasarkan analisis filogeni menunjukkan kedua-dua spesies bakteria ini adalah jauh berbeza dari segi jujukan dengan kumpulan patogen utama manusia dan haiwan seperti B. pseudomallei and B. mallei (Eberl \& Vandamme 2016; Mohd-Padil et al. 2017).

Kajian ini telah mengenal pasti dua Burkholderia sp. yang berada dalam kumpulan yang sama dengan Burkholderia sp. patogen oportunis iaitu B. stagnalis and B. cepacia (Rajah 5). B. cepacia dikenali sebagai antagonis semula jadi kepada jangkitan kulat dalam pertanian kerana kebolehannya menghasilkan sebatian antikulat seperti asid fenilasetik, asid hidrosinnamik dan asid 4-hidroksifenilasetik (Mao et al. 2006). Kajian lepas juga telah mengenal pasti beberapa bakteria endofit seperti Pseudomonas aeruginosa, B. cepacia dan P. syringae yang berpotensi sebagai agen kawalan biologi terhadap $G$. boninense (Ramli et al. 2016). Namun begitu, nilai PIRG yang direkodkan oleh setiap bakteria endofit tersebut adalah lebih rendah (40 - 70\%) berbanding nilai PIRG daripada bakteria pencilan kajian ini. Selain bertindak sebagai antagonis kepada patogen tumbuhan, beberapa penemuan baharu menunjukkan hubungan rapat antara beberapa Burkholderia sp. dan tumbuhan perumah seperti interaksi mikrob-tumbuhan antara $B$. phytofirmans PsJN dan akar bawang (Esmaeel et al. 2018). Burkholderia sp. ini membentuk hubungan simbiosis secara endofit dengan tumbuhan perumahnya, yang seterusnya meningkatkan kebolehan bakteria tersebut melindungi tumbuhan perumahnya dari serangan patogen dan meningkatkan kerintangan tumbuhan dari tekanan suhu rendah dan kepekatan garam yang tinggi (Esmaeel et al. 2018; Sheibani-Tezerji et al. 2015).

\section{KESIMPULAN}

Kajian ini telah mengenal pasti beberapa bakteria tanah pencilan tempatan yang mempunyai kesan perencatan tinggi terhadap $G$. boninense secara in vitro. Analisis perbandingan jujukan DNA menggunakan 16S rRNA sebagai DNA rujukan mendapati bakteria tersebut mempunyai kesamaan yang tinggi dengan $S$. gelaticus, B. cepacia dan B. stagnalis. Kumpulan bakteria ini mungkin menghasilkan metabolit sekunder khusus yang mampu merencat pertumbuhan kulat patogen $G$. boninense. Kajian lanjutan diperlukan untuk mengenal pasti jenis metabolit sekunder yang berpotensi merencat pertumbuhan $G$. boninense yang berpadanan dengan matlamat utama penyelidikan iaitu penghasilan pestisid berasaskan mikrob dalam menangani masalah BSR di ladang kelapa sawit.

\section{PENGHARGAAN}

Projek ini dibiayai oleh Universiti Kebangsaan Malaysia [nombor geran GGPM-2017-071].

\section{RUJUKAN}

Arif, M.A., Roslan, A., Idris, A.S. \& Ramle, M. 2011. Economics of oil palm pests and Ganoderma diseases and yield loses. In Proceedings of the 3rd International Seminar Integrated Oil Palm Pests and Management. MPOB-IOPRI. hlm. 83-98. 
Chong, K.P., Dayou, J. \& Alexander, A. 2017. Detection and Control of Ganoderma Boninense in Oil Palm Crop. Springer: Berlin. hlm. 1-50.

Eberl, L. \& Vandamme, P. 2016. Members of the genus Burkholderia: Good and bad guys. F1000Res. 5: F1000 Faculty Rev-1007.

El Khoury, R., Choque, E., El Khoury, A., Snini, S.P., Cairns, R., Andriantsiferana, C. \& Mathieu, F. 2018. OTA prevention and detoxification by actinobacterial strains and activated carbon fibers: Preliminary results. Toxins 10(4): 137.

Esmaeel, Q., Miotto, L., Rondeau, M., Leclère, V., Clément, C., Jacquard, C., Sanchez, L. \& Barka, E.A. 2018. Paraburkholderia phytofirmans PsJN-plants interaction: From perception to the induced mechanisms. Front Microbiol. https://doi.org/10.3389/fmicb.2018.02093

Halim, M., Muhaimin, A.M.D., Syarifah-Zulaikha, S.A., Nor Atikah, A.R.M., Masri, M.M. \& Yaakop, S. 2017. Evaluation of infestation in parasitoids on Metisa plana Walker (Lepidoptera: Psychidae) in three oil palm plantations in Peninsula Malaysia. Serangga 22(2): 135-149.

Heuer, H., Krsek, M., Baker, P., Smalla, K. \& Wellington, E.M. 1997. Analysis of actinomycete communities by specific amplification of genes encoding 16S rRNA and gelelectrophoretic separation in denaturing gradients. Applied and Environmental Microbiology 63(8): 3233-3241.

Hong, C.E. \& Park, J.M. 2016. Endophytic bacteria as biocontrol agents against plant pathogens: Current state-of-the-art. Plant Biotechnology Reports 10(6): 353-357.

Hushiarian, R., Yusof, N.A. \& Dutse, S.W. 2013. Detection and control of Ganoderma boninense: Strategies and perspectives. SpringerPlus 2(1): 1-12.

Ibrahim, M.S., Abu Seman, I., Rusli, M.H., Izzuddin, M.A., Kamarudin, N., Hashim, K. \& Abd Manaf, Z. 2020. Surveillance of Ganoderma disease in oil palm planted by participants of the smallholders replanting incentive scheme in Malaysia. Journal of Oil Palm Research 32(2): 237-244.

Isaac, I.L., Walter, A.W.C.Y., Bakar, M.F.A., Idris, A.S., Bakar, F.D.A., Bharudin, I. \& Murad, A.M.A. 2018. Transcriptome datasets of oil palm pathogen Ganoderma boninense. Data in Brief 17: 1108-1111.

Kumar, S., Stecher, G. \& Tamura, K. 2016. MEGA7: Molecular evolutionary genetics analysis version 7.0 for bigger datasets. Molecular Biology and Evolution 33(7): 1870-1874.

Kushairi, A., Ong-Abdullah, M., Nambiappan, B., Hishamuddin, E., Bidin, M., Ghazali, R., Subramaniam, V., Sundram, S. \& Parveez, G.K.A. 2019. Oil palm economic performance in Malaysia and R\&D progress in 2018. Journal of Oil Palm Research 31(2): 165-194.

Law, J.W.F., Ser, H.L., Ab Mutalib, N.S., Saokaew, S., Duangjai, A., Khan, T.M., Chan, K.G., Goh, B.H. \& Lee, L.H. 2019. Streptomyces monashensis sp. nov., a novel mangrove soil actinobacterium from East Malaysia with antioxidative potential. Scientific Reports 9(1): 1-18.

Law, J.W.F., Ser, H.L., Khan, T.M., Chuah, L.H., Pusparajah, P., Chan, K.G., Goh, B.H. \& Lee, L.H. 2017. The potential of Streptomyces as biocontrol agents against the rice blast fungus, Magnaporthe oryzae (Pyricularia oryzae). Frontiers in Microbiology https://doi.org/10.3389/fmicb.2017.00003.

Lim, C.K., Ahmad, R., Marzuki, N.F., Goh, Y.K., Azizan, K.A., Goh, Y.K. \& Goh, K.J. 2018a. Optimization of metabolite extraction protocols for untargeted metabolite profiling of mycoparasitic Scytalidium parasiticum using LC-TOF-MS. Sains Malaysiana 47(12): 3061-3068.

Lim, P., Gansau, J.A. \& Chong, K.P. 2018b. Streptomyces spp. a potential biocontrol agent against Ganoderma boninense of basal stem rot. Journal of Oil Palm Research 30(2): 265-275.

Luqman, H.A., Noor Nasuha, A.A., Dzulhelmi, M.N., Nurul Fatihah, A.L., Muhamad Fahmi, M.H., Teo, T.M., Idris, A.G. \& Izfa Riza, H. 2018. Diversity and composition of beetles (Order: Coleoptera) in three different ages of oil palms in Lekir oil Palm Plantation, Perak, Malaysia. Serangga 23(1): 58-71.

Madihah, A.Z., Idris, A.S., Kamaruddin, S., Bharudin, I., Abu Bakar, F.D. \& Abd Murad, A.M. 2019. Identification and characterization of a mating signalling gene from an oil palm pathogen, Ganoderma boninense. In AIP Conference Proceedings. AIP. 2111.

Madihah, A.Z., Maizatul-Suriza, M., Idris, A.S., Bakar, M.F.A., Kamaruddin, S., Bharudin, I., Abu Bakar, F.D. \& Murad, A.M.A. 2018. Comparison of DNA extraction and detection of Ganoderma, causal of basal stem rot disease in oil palm using loop-mediated isothermal amplification. Malaysian Applied Biology 47(5): 119-127.

Mao, S., Lee, S.J., Hwangbo, H., Kim, Y.W., Park, K.H., Cha, G.S., Park, R.D. \& Kim, K.Y. 2006. Isolation and characterization of antifungal substances from Burkholderia sp. culture broth. Current Microbiology 53(5): 358-364.

Maznah, Z., Halimah, M., Ismail, S. \& Idris, A.S. 2015. Dissipation of the fungicide hexaconazole in oil palm plantation. Environmental Science and Pollution Research 22(24): 19648-19657.

Mohd-Padil, H., Damiri, N., Sulaiman, S., Chai, S.F., Nathan, S. \& Firdaus-Raih, M. 2017. Identification of sRNA mediated responses to nutrient depletion in Burkholderia pseudomallei. Scientific Reports 7(1): 1-11.

Muniroh, M.S., Nusaibah, S.A., Vadamalai, G. \& Siddique, Y. 2019. Proficiency of biocontrol agents as plant growth promoters and hydrolytic enzyme producers in Ganoderma boninense infected oil palm seedlings. Current Plant Biology 20: 100116.

Nadarajah, K.K. 2016. Rhizosphere interactions: Life below ground. In Plant-Microbe Interaction: An Approach to Sustainable Agriculture, edited by Choudhary, D.K., Varma, A. \& Tuteja, N. Springer: Singapore. https://doi. org/10.1007/978-981-10-2854-0_1.

Naher, U., Sarkar, M.I., Jahan, A., Maniruzzaman, M., Choudhury, A.K., Kalra, N. \& Biswas, J. 2019. Nutrient mineralization and soil biology as influenced by temperature and fertilizer management practices. Sains Malaysiana 48(4): 735-744. 
Nusaibah, S., Saad, G. \& Tan, G.H. 2017. Antagonistic efficacy of Trichoderma harzianum and Bacillus cereus against Ganoderma disease of oil palm via dip, place and drench (DPD) artificial inoculation technique. International Journal of Agriculture and Biology 19(2): 299-306.

Priwiratama, H. \& Susanto, A. 2014. Utilization of fungi for the biological control of insect pests and Ganoderma disease in the Indonesian oil palm industry. Journal of Agricultural Science and Technology A 4(2): 103-111.

Ramli, N.R., Mohamed, M.S., Abu-Seman, I., Madihah, A.Z. \& Mohamad, N. 2016. The potential of endophytic bacteria as a biological control agent for Ganoderma disease in oil palm. Sains Malaysiana 45(3): 401-409.

Remali, J., Zin, N.M., Ng, C.L., Aizat, W.M. \& Tiong, J.J.L. 2019. Fenazin sebagai potensi antibiotik baru daripada Streptomyces kebangsaanensis. Sains Malaysiana 48(3): 543-553.

Retnowati, D., Solihin, D., Ghulamahdi, M. \& Lestari, Y. 2018. New information on the potency of sponge-associated actinobacteria as producer of plant growth-promoting bioactive compounds. Malaysian Applied Biology 47(6): 127-135.

Shahbazi, P., Musa, M.Y., Geok, Y.A.T., Avin, F.A., Wee, F.A.T. \& Vikineswary, S. 2014. In vitro and in vivo evaluation of Streptomyces suppressions against anthracnose in chili caused by Colletotrichum. Sains Malaysiana 43(5): 697-705.

Shariffah-Muzaimah, S.A., Idris, A.S., Madihah, A.Z., Dzolkhifli, O., Kamaruzzaman, S. \& Maizatul-Suriza, M. 2017. Characterization of Streptomyces spp. isolated from the rhizosphere of oil palm and evaluation of their ability to suppress basal stem rot disease in oil palm seedlings when applied as powder formulations in a glasshouse trial. World Journal of Microbiology and Biotechnology 34(1): 15.

Shariffah-Muzaimah, S.A., Idris, A.S., Madihah, A.Z., Dzolkhifli, O. \& Kamaruzzaman, S. 2015. Isolation of actinomycetes from rhizosphere of oil palm (Elaeis guineensis Jacq.) for antagonism against Ganoderma boninense. Journal of Oil Palm Research 27(1): 19-29.
Sheibani-Tezerji, R., Rattei, T., Sessitsch, A., Trognitz, F. \& Mitter, B. 2015. Transcriptome profiling of the endophyte Burkholderia phytofirmans PsJN indicates sensing of the plant environment and drought stress. MBio 6(5): e0062115.

Singh, S., Bhatnagar, S., Choudhary, S., Nirwan, B. \& Sharma, K. 2018. Fungi as biocontrol agent: An alternate to chemicals. In Fungi and Their Role in Sustainable Development: Current Perspectives, edited by Praveen, G. \& Joginder, S. Springer: Singapore. hlm. 23-33.

Sujarit, K., Mori, M., Dobashi, K., Shiomi, K., Pathom-aree, W. \& Lumyong, S. 2020. New antimicrobial phenyl alkenoic acids isolated from an oil palm rhizosphere-associated actinomycete, Streptomyces palmae CMU-AB204T. Microorganisms 8(3): 350.

Aqilah Yusoff, Fatin Humairah M. Ashaari, Muhammad Asyraff Abd Samad, Anis Farhan Fatimi Ab Wahab \& Izwan Bharudin* Department of Biological Sciences and Biotechnology

Faculty of Science and Technology

Universiti Kebangsaan Malaysia 43600 UKM Bangi, Selangor Darul Ehsan Malaysia

Anis Farhan Fatimi Ab Wahab FGV Innovation Centre (Biotechnology)

Pt. 23417 Lengkuk Teknologi

71760 Bandar Enstek, Negeri Sembilan Darul Khusus Malaysia

Izwan Bharudin*

Pusat Penyelidikan Bukit Fraser (PPBF)

Fakulti Sains dan Teknologi

Universiti Kebangsaan Malaysia

43600 UKM Bangi, Selangor Darul Ehsan

Malaysia

*Pengarang untuk surat-menyurat; email: ibb@ukm.edu.my

Diserahkan: 29 Mac 2020

Diterima: 16 April 2021 